\author{
Глигор М. Самарџић \\ Универзитет у Приштини \\ Филозофски факултет, Косовска Митровица \\ Катедра за историју \\ e-mail: gligorijas@yahoo.com
}

\title{
ЈУПИТЕР И ЊЕГОВИ ЕПИТЕТИ (КАРАКТЕР ПОСВЕТА) СА ЈУГА ПРОВИНЦИЈЕ ГОРЊЕ МЕЗИЈЕ ${ }^{1}$
}

(Неколико примјера са Косова и Метохије)

\begin{abstract}
Апстракт: На југу римске провинције Горње Мезије (Косово и Метохија), као и у свим подручјима која су некада била у саставу Римског ијарства, нађени су епиграфски споменици који свједоче о религиозности римских грађана. Римљани (војници, колонисти), са собом су донијели поштовање култова божанстава римског државног пантеона од којих је најпоштованији био врховни римски бог Јупитер Капитолски. Он се јавља са различитим епитетима који стоје уз његово име. На југу провинције Горње Мезије (Косово и Метохија) нађен је скроман број споменика посвећених Јупитеру Капитолском, који нам служе као главни извор за упознавање са ширењем овог култа. Готово сви пронађени натписи са Косова и Метохије посветног су карактера и указују на комплексну природу Јупитеровог култа и различите епитете који стоје уз његово име.

Кључне ријечи: Јупитер, епитет, Римско царство, провинција Горња Мезија, Косово и Метохија.
\end{abstract}

Данашње Косово и Метохија ушло је у сферу римске спољне политике на прелазу из III у II вијек прије н. е. Римљани су након готово два вијека ратовања са племенима средњег Балкана - Дарданцима, Скордисцима и Мезима - освојили територију између сјеверне границе провинције Македоније и Дунава (28. године прије н. е.). Римским освајањем источне обале Јадрана и његовог залеђа почетком I вијека н. е. на овај простор долазе римски трговци, колонисти и војници носећи са собом све тековине римске цивилизације. Та цивилизација је на различите начине продирала међу старосједилачко становништво, а извршила је утицај и на аутохтоне култове и вјеровања ширећи оне који су припадали изворној римској религији. ${ }^{2}$

У овом раду разматрамо култ Јупитера и различите епитете овог божанства, осим раније обрађених капитолских (Iuppiter Optimus Maximus), ${ }^{3}$ који су посвједочени на Косову и Метохији у римско доба. Познавање религије и култова одређене етничке

1 Рад је резултат истраживања у оквиру научноистраживачког пројекта III 47023, Косово $u$ Метохија између националног идентитета и евроинтеграција, који финансира Министарство просвете, науке и технолошког развоја Републике Србије.

2 Papazoglu 1969, 143; Папазоглу 1988, 163-164; Mirković 1968, 22; Лома 2010, 22; Самарџић 2020, 9-16.

3 Самарџић 2019, 423-432. 
скупине не само да омогућује расвјетљавање степена њеног духовног развитка, већ даје и шири увид у етничку, политичку и друштвену слику одређене територије (области). У овом случају, трагови домаћих култова и прожимања старих традиција са новом, римском религијом указују на резултате и степен романизације. Домаће становништво с временом је прихватало поштовање римских божанстава, а култна изједначавања познајемо под термином interpretatio Romana, по којој се домаће божанство назива именом одговарајућег римског божанства. О значају и опсегу романизације на подручју Косова и Метохије (југ Горње Мезије) данас нам свједоче остаци материјалне културе. ${ }^{4}$

Епиграфски вотивни споменици су најзначајнији извор за изучавање религије на Косову и Метохији у римско доба и свједочанства о вјерским схватањима становништва на југу Горње Мезије. ${ }^{5}$ Поједини натписи откривају прилике и околности у којима су испуњавани завјети, док неки свједоче о подизању или обнови храмова и светилишта, указујући истовремено на чињеницу да је романизација дубоко продрла и у област духовног живота у дарданском дијелу Горње Мезије. Током II и III вијека, духовни живот становника на овим просторима у сфери култа и вјеровања био је сложеног карактера, а огледа се у споменицима посвећеним различитим римским, грчким, оријенталним и домаћим боговима. Већина сачуваних споменика подигнута је боговима римског пантеона. Најчешће су то посвете Јупитеру Капитолском (Iuppiter Optimus Maximus), који се углавном јавља самостално, ријетко у заједници са другим боговима. На сачуваним епиграфским споменицима ми смо анализирали епиграфска свједочанства са Косова и Метохије на којима је Јупитер, осим капитолских, посвједочен различитим епитетима и разнородним дедикантима. ${ }^{6}$

У Кострцу код Косовске Митровице нађена је вотивна ара $(1,20$ х 0,43 х 0,50 м) на којој се Јупитер јавља са скраћеним епитетом $C$ ( ) који се може читати као C(ulminalis), C(apitolinus) и C(ohortalis). Текст натписа гласи: I(ovi) O(ptimo) M(aximo) C( ) / T(itus) Ael(ius) Avitus / dec(urio) m(unicipi) Ulp(ianorum) /v(otum) s(olvit) l(ibens) m(erito). ${ }^{7}$ Натпис се датује у другу половину II или прву половину III вијека. ${ }^{8}$ На основу мјеста налаза споменика (царски домен), као и на основу дедикантове функције (декурион муниципијума Улпијане) сматра се да је ријеч о Јупитеру са епитетом C(apitolinus). ${ }^{9}$ Значајно је истаћи да је Тит Елије Авит, као декурион муниципијума Улпијана, припадао елити која је управљала градом.

Јупитер се, поред већ поменутог натписа из Косовске Митровице, појављује са Јуноном на фрагментованом споменику који је пронађен на подручју Клокота у селу Врбовцу (Витина), на локалитету Грмен, и носи епитет Cohortalis. Текст натписа гласи: [I(ovi)] O(ptimo) M(aximo) / [Coh]ortali / Iunoni / Reg(inae) / [- - -.$^{10}$ На овом епиграфском споменику Јунона има епитет Regina. ${ }^{11}$ Епитет Cohortalis се користи за Јупитера у војном контексту и означава га као заштитника кохорте. Међутим, из текста овог споменика не може се закључити о којој је јединици ријеч. Ништа не можемо рећи ни када је датација овог споменика у питању, јер сачувани текст не даје довољно података.

4 Čerškov 1969, 64-69; Bojanovski 1988, 68; Mirdita 2007, 13-21, 57, 92; Самарџић 2015, 321-322; Mirdita 2015, 349, 404-405; Самарџић 2019, 423-432; Самарџић 2020, 201-208.

5 Ferjančić 2010, 466; Самарџић 2020, 201-202.

6 Вулић 1941/1948, 102; Čerškov 1969, 65; Domaszevski 1975, 22; Bodora 1989, 1082; Sinobad 2010, 162; Самарџић 2019, 423-432; Самарџић 2020, 201-208.

7 ILJug 1397. Уп. Вулић 1931, 89 бр. 206; Вулић 1941/1948, 102 бр. 222; Mirdita 2007, 92.

8 Mirdita 1981, 267 br. 335 (29).

9 Mirdita 2007, 104.

10 ILJug 1427. УП. Вулић 1941/1948, 35 бр. 83; Čerškov 1969, 65; Mirdita 2007, 95.

11 Marić 1933, 140; Вулић 1941/1948, 35 бp. 83; Čerškov 1969, 65; Ferri 2012a, 141-142. 
3. Мирдита наводи да се у епиграфском материјалу Косова и Метохије Јупитер појављује и са епитетом Depulsor. ${ }^{12}$ Ријеч је о браниоцу, тј. заштитнику. Има мишљења да је Iuppiter Depulsor божанство које одбија свако зло, ${ }^{13}$ штити од болести и разних епидемија, ${ }^{14}$ односно одбија варваре који угрожавају границе Римског царства. ${ }^{15}$ Док поједини истраживачи сматрају да је он панонског поријекла, а да је средиште његовог култа био Петовион у Панонији, ${ }^{16}$ љ. Зотовић сматра да овај култ не може бити балканског поријекла. Разлог таквом стајалишту налази у чињеници да је број вотивних apa посвећених овом божанству на овом подручју веома мали. ${ }^{17}$ Поменути епитет Depulsor Мирдита реконструише на једном епиграфском споменику који је случајно откривен 1951. године у Улпијани: [Iovi Depol(!)/sori?] / [Sur] us pro / [se] et suis / ex voto posuit. Он натпис датује у II вијек ${ }^{18}$ и претпоставља да би дедикант из Улпијане могао бити Илир или Трачанин. ${ }^{19}$ Није јасно на основу чега је Мирдита извршио реконструкцију текста као [Iovi Depol(!)/sori?]. Исто тако, не знамо на основу чега је на овом натпису реконструисано име [Sur]us. Наиме, на натпису је сачуван само номинативни наставак $u s$, тако да би могло бити ријечи о било којем имену.

Јупитер се на Косову и Метохији појављује и с епитетом Melanus. Посвједочен је на једном жртвенику из Цркве Св. Николе код Призрена, а текст натписа гласи: I(ovi) O(ptimo) M(aximo) / Melano / Martinus [Se]ptimius / [Cae]sonius / [Gall]icanus / [exvoto(?)] $\operatorname{pos}\left(\right.$ uerunt). ${ }^{20}$ 3. Мирдита натпис датује у другу половину II или у прву половину III вијека, ${ }^{21}$ док Д. Грбић наводи да би Јупитер Melanus могао бити једнак Зевсу који носи епитет Melenus, посвједоченом на Трајановом новцу фригијског града Дорилејона (Мала Азија), те да су поштовање овог божанства у Мезију донијели са собом досељеници који су дошли зарад трговине или бављења занатима којима су се бавили у своме завичају. ${ }^{22}$ То би се слагало са претпоставком С. Душанића да су дедиканти овог споменика досељеници, Битињани, из Мале Азије, који су жртвеник посветили Зевсу из Меле, заштитнику овог мјеста у Битинији, чији епитет Melanus је битински доризам за Melenus који се јавља на Трајановом новцу фригијског града Дорилејона. Присуство ова четири дедиканта у овим нерударским крајевима, према овом аутору, може се објаснити раширеношћу битинских култова из области у Дарданији гдје је њихово присуство било везано за рударску производњу, или су пак пролазили кроз ове крајеве и оставили за собом ову посвету. ${ }^{23}$ Према именима дедиканата не може се закључити да су дошли из хеленофоних крајева, али како је евидентно одсуство гентилиција може се претпоставити да је ријеч о перегринима, робовима или ослобођеницима који су живјели и радили у рудоносним подручјима ${ }^{24}$ те подлегли романизацији. ${ }^{25}$

12 Mirdita 2007, 101.

13 Toutain 1967, 284; Kolendo 1969, 111-117; Kolendo 1989, 1046.

14 Egger 1929, 201; Mirdita 2007, 101.

15 Pflaum 1953, 454.

16 Pflaum 1955, 153; Kolendo 1969, 11; Latte 1976, 154; Kos-Šašel 1999, 121-129.

17 Zotović 1967, 40-41.

18 Mirdita 1981, 251 br. 234 (33).

19 Mirdita 2007, 102.

20 ILJug 531a = AE 1972, 501.

21 Mirdita 1981, 262 br. 303 (8).

22 Grbić 2015, 129-130.

23 Душанић 1971, 256-257.

24 Исто, 257.

25 Grbić 2015, 130. 
На епиграфском материјалу са Косова и Метохије забиљежен је и култ Јупитера Долихена. Он је посвједочен на подручју Улпијане, на вотивној ари (0,70 х 1,50 х 0,20 м) која је нађена у околини Грачанице. Текст натписа гласи: I(ovi) O(ptimo) M(aximo) D(olicheno) / pro salute d[[d(ominorum) nn(ostrorum)]] / Imp(eratoris) Aug(usti) / Victor Demetri et De/metrius Ambibi sace[r]/dotes eiusdem dei s(olverunt) v(otum) [- - ] / [- - . .26 Брисање дијела царске титулатуре у другом реду (damnatio memoriae) указује на владавину династије Севера, прије свега Каракале, када је са споменика брисано име његовог брата Гете. ${ }^{27}$ Код оба свештеника јавља се грчко име Demetrius. ${ }^{28}$ Оно се иначе јавља у натписима широм Царства (Италија, Шпанија, Белгијска Галија, Нарбонска Галија, Далмација, Панонија, Норик, Дакија, Британија, Лугдунска Галија, Горња Мезија, Доња Мезија, Реција). У случају првог дедиканта, Виктора, то је име његовог оца, док је у случају другог дедиканта ријеч о његовом имену. Оно казује да би двојица свештеника могли бити поријеклом из неке од хеленофоних провинција Римског царства. Ниједан од двојице дедиканата нема nomen gentile, који свједочи да је ријеч о римским грађанима, ${ }^{29}$ а притом је посебно занимљиво име оца другог дедиканта. Наиме, Ambibius ${ }^{30}$ је доста ријетко име и јавља се на скромном броју натписа пронађених широм некадашњег Римског царства. ${ }^{31}$

3. Мирдита наводи и да се на једној вотивној ари која је пронађена у Лапљем Селу Јупитер појављује с епитетом Melcid. Његова реконструкција текста гласи: I(ovi) O(ptimo) M(aximo) / Melcid / Ael(ius) Octa/vianus ve(teranus)cum / suis v(otum) p(osuit). ${ }^{32}$ Мирдита, на основу Јупитеровог атрибута, претпоставља да се ради о досељенику из Мале Азије, а на темељу царског гентилиција дедиканта (грађанско право добио од Каракале 212. године) и палеографских карактеристика натписа споменик оквирно датује у III вијек. ${ }^{33}$ М. Паровић Пешикан и Ф. Пеја овај натпис читају на сљедећи начин: I(ovi) O(ptimo) M(aximo) / Mel(ano) Cid(iesso) / Ael(ius) Octa/vianus / v(ir) e(gregius) cum / suis $v$ (otum) p(osuit). ${ }^{34}$ Паровић Пешикан скраћеницу $\operatorname{Mel}($ ) разрјешава као Mel(ano), позивајући се на горе поменути споменик из Призрена, док за други епитет не даје рјешење, за разлику од Пеје који ову скраћеницу разрјешава као Cid(iesso) (по имену једног мањег мјеста у западном дијелу Фригије - Kidyessos). Паровић Пешикан и Пеја сматрају да су ови Јупитерови епитети везани за малоазијске градове па се, по њиховом мишљењу, оправдано може говорити о досељеницима из Мале Азије у Дарданију, чије је присуство највјероватније везано за рударску производњу. ${ }^{35}$

26 ILJug 1416. Уп. Вулић 1931, 192 бр. 510; Марић 2003, 110, 154; Čerškov 1969, 67; Mirdita 2007, 71. 27 Hörig/ Schwertheimer 1987, 86 nr. 115; Mirdita 1981, 248 br. 219 (18).

28 LGPN vol. I, IA.

29 Matijašić 2002, 59.

30 OPEL I 91.

31 Натпис из Доње Мезије: [Ant]oniae Gnesiae sanctissim(a)e pientissim(a)e L(ucius) Porcius Ambibius con/[iunx] aedilicius bis magistratus sacerdos designatus civitati[s] / [Ul]piae Nicopoli(s) ad Histrum uxori ben[e] merent [i et] sib[i] posuit (AE 1991, 1376); [Ant]oniae Gnesiae sanctissim(a)e pientissim(a)e L(ucius) Porcius Ambibius con/[iunx] aedilicius bis magistratus sacerdos designatus civitati[s] / [Ul]piae Nicopoli(s) ad Histrum uxori ben[e] merent [i et] sib[i] posuit (AE 1991, 1376); Натпис из Рима: D(is) M(anibus) / Ambibiae(!) / [O]nesimeni / [vixit] ann(os) XIII (AE 1977, 0125); Натпис из Горње Мезије (са простора данашње Македоније): Ambibia M/aria vix[it [- - - (IMS VI 85).

32 Mirdita 1981, 251 br. 236 (35); Mirdita 2007, 39.

33 Mirdita 1980, 187; Ферјанчић 2002, 291.

34 Parović-Pešikan 1982, 70; Peja 1984, 60.

35 Parović-Pešikan 1982, 70-71; Peja 1984, 60-61. 
На основу свега наведеног можемо рећи да култ Јупитера чини саставни дио римске културе становништва провинције Горње Мезије (Косово и Метохија) те да се појављује са романизацијом провинције, најприје у урбаним средиштима - гдје се у највећој мјери и манифестује римски начин живота. Отуда и највећи број података о овом култу потиче управо из урбаних средишта и углавном су старији од података у руралним срединама.

Видимо да се на споменицима Косова и Метохије Јупитер најчешће појављује сам, али и у Капитолској тријади (са Јуноном и Минервом), те у друштву других божанстава. Најчешћи облик дедикције је у скраћеници IOM. Међутим, видимо и да је на овом подручју сачуван значајан број епиграфских споменика на којима су осим капитолских присутни сљедећи Јупитерови епитети: Capitolinus, Cohortalis, Melcid, Melano, Depulsor, Dolicheno. Ти споменици потичу углавном са локалитета некадашњих храмова, светилишта и приватних култних простора, али су понекад и резултат случајних налаза са локалитета који нису везани уз култни ритуал.

Наведени епитети упућују на закључак да је настанак више Јупитерових култова посвједочених на југу Горње Мезије обиљежен синкретизмом различитих културних елемената. Наиме, осим аутохтоног становништва, на југу Горње Мезије у античко доба је живјело и становништво досељено из других дијелова Римског царства, које је са собом донијело властиту материјалну и духовну културу. Тако су поред Јупитера Капитолског, који је представљао окосницу државне службене религије, присутни били и његови култови настали синкретизмом римских и оријенталних религијских елемената, прије свега оних из хеленофоних подручја. Те култове су на подручју Горње Мезије проширили становници оријенталног поријекла (везано за рударску производњу) и припадници римске војске који су боравили у источним провинцијама Царства.

\section{СКРАЋЕНИЦЕ}

AE L'Annee epigraphique. Revue des publications epigraphiques relatives a l'Antiquite romaine, Paris 1977, 1991.

ANRW Aufstieg und Niedergang der römischen Welt. Geschiehte und Kultur Roms im Spiegel der neueren Forschung, Berlin - New York 1989.

ILJug Inscriptiones Latinae quae in Iugoslavia. Ljubljana 1963, 1978, 1986.

JÖAI Jahreshefte des Österreichischen archäologischen Instituts. Wien 1929.

LPGN Lexicon of Greek Personal Names, Vol. I, Oxford 1988.

OPEL Onomasticon provinciarum Europae Latinarum, Vol. I, Budapest-Wien 1994.

CIL Corpus Inscriptiones Latinarum, Berolini 1873.

\section{Извори}

L'Annee epigraphique, (1980): Revue des publications epigraphiques relatives a l'Antiquite romaine. Paris. 
Inscriptions de la Mésie Supérieure, Vol. VI (ed. B. Dragojević-Josifovska), Centre d'études épigraphiques et numismatiques, Beograd 1982.

Lexicon of Greek Personal Names, Vol. I, Oxford 1988.

Onomasticon provinciarum Europae Latinarum Vol. I (ed. B. Lőrincz et F. Redö), Budapest 1994.

Corpus Inscriptionum Latinarum, (1873): Consilio et auctoritate Academiae litterarum regiae. Berolini: Borussicae editum, ed. Th. Mommsen, Voll. III.

Šašel, A. et J., (1963): Inscriptiones Latinae quae in Iugoslavia Inter annos MCMXL et MCMLX repertae et editae sunt. Ljubljana: Situla5, Narodni muzej Slovenije.

Šašel, A. et J., (1978): Inscriptiones Latinae quae in Iugoslavia Inter annos MCMLX et MCMLXX repertae et editae sunt. Ljubljana: Situla19, Narodni muzej Slovenije.

Šašel, A. et J.,( 1986): Inscriptiones Latinae quae in Iugoslavia Inter annos MCMII et MCMXL repertae et editae sunt. Ljubljana: Situla 25, Narodni muzej Slovenije.

\section{Литература}

Bodora, A. (1989): „Die Griechisch-römischen Kulte in der Provinz Dacia und das Nachwirken der einheimischen Traditionen“. y: ANRW II 18, 2/1989, 1082-1131.

Bojanovski, I. (1988): Bosna i Hercegovina u antičko doba. Sarajevo:ANU BiH, Djela, LXVI, CBI, 6.

Вулић, Н. (1931): „Антички споменици наше земље“. у: Споменик LXXI, 42- 135, 179-182, 195, 208-211, 213-215, 274, 279, 321, 325, 519. $1-279$.

Вулић, Н. (1941/1948): „Антички споменици наше земље“. у: Споменик XCVIII,

Grbić, D. (2015): „Ancestral Gods and Ethnic Associations: Epigrphic Examples from Upper Moesia“: y: Lucida intervalla, 44, 125-136.

Domaszewski, A. (1975): Die Religion des römischen Heeres. New York: Annopress.

Душанић, С. (1971): „Нови Антинојев натпис и metalla municipii Dardanorum“. y: Živa antika, god. XXI, sv. 1, 241-261.

Egger, R. (1929): „Ausgrabungen in Feistritz an Drau“. y: JÖAI, XXV, 216-215.

Зотовић, Љ. (1967): „Култ Јупитера Depulsora. Опредељивање и распрострањеност његових споменика у Југославији“. у: Старинар н. с., XVII(1966/1967), $37-43$.

Latte, K. (1976): Römische Religions geschichte. Mümcchen: Beck.

Kolendo, J. (1969): „Inscription de l' an 227 enl'honneur de Jupiter Depulsor découverte à Novae“. y: Archaeologia 19, 117.

Kolendo, J. (1989): „Le cultede Jupiter Depulsor et les incursions des Barbares“. y: ANRW II 18, 2/1989, 1062-1076.

Kos-Šašael, M.(1999): Pre-Roman Divinities of the Eastern Alps and Adriatic. Ljubljana: Narodni muzej Slovenije.

Лома, С. (2010): „Домородачко становништво Косова и Метохије у римско доба у светлу антропонимије“. у: ( ур. Д. Маликовић), Косово и Метохија у циивилизацијским токовима, књ. 3, Косовска Митровица, Филозофски факултет Универзитета у Приштини, Косовска Митровица 19-40.

Марић, Р. (1933): Антички култови у нашој земљи. Београд: Издања задужбине Луке Ћеловића - Требињца.

Марић, Р. (2003): Антички култови у нашој земљи. Београд: Чигоја (репринт).

Matijašić, R. (2002): Uvod u latinsku epigrafiku. Pula: Filozofski fakultet Pula. 
Mirdita, Z. (1980): „Novitates epigraphicae e Dardania collectae“. y: Arheološki vestnik, XXXI, 186-198.

Mirdita, Z. (1981): Antroponimia e Dardanisë në kohën romake. Prishtinë: Rilindija.

Mirdita, Z. (2007): Religija i kultovi Dardanaca i Dardanije u antici. Zagreb: Hrvatski institut za povijest. povijest.

Mirdita, Z. (2015): Dardanaci i Dardanija u antici. Zagreb: Hrvatski institut za

Mirković, M. (1968): Rimski gradovi na Dunavu u Gornjoj Meziji. Beograd: Arheološko društvo Jugoslavije.

Паровић-Пешикан, М. (1982): „Античка Улпијана према досадашњим истраживањима“. у: Старинар XXXII, 57-74.

Peja, F. (1984): „Jedan zanimljiv natpis sa Ulpiane“. y: Glasnik muzeja Kosova $i$ Metohije, XIII XIV, 59-62.

Pflaum, H. G. (1953): „Jupiter Depulsor“. y: Mélanges Isidore Lévy (Annuaire de l’ Institut de Philologie et d'Historie orientales et slaves XIII/1953), 445-460.

Pflaum, H. G. (1955): „Deux carrières équestres de Lambèse et de Zana (Diana Veteranorum)“. y: Libyca, III, 123-154.

Toutain, J. (1967): Les cultes paiens dans l' Empire romain I. Les provinces Latines. Roma: Edizione anastatica.

Papazoglu, F. (1969): Srednjobalkanska plemena u predrimsko doba. Sarajevo: Djela, knj. XXX, CBI knj. 1, ANUBiH.

Папазоглу, Ф. (1988): „Илирска и дарданска краљевина; поријекло и развој, структура, хеленизащија и романизащија “. у: (при. и ур. М. Гарашанин), Илири и Албанции, САНУ, Београд, 145-173.

Самарџић, Г. (2015): Источна Херцеговина у римско доба. Косовска Митровица: Филозофски факултет.

Самарџић, Г. (2019): „О духовном утицају Рима на југ Горње Мезије (О култу Јупитера са Косова и Метохије)“. у: Црквене студије, 16/2, 423-432.

Самарџић, Г. (2020): Косово и Метохија у римско доба. Косовска Митровица: Филозофски факултет.

Sinobad, M. (2010): „Jupiter i njegovi štovatelji u svjetlu epigrafskih izvora na području Hrvatske“. y Opuscvula Arhaeologica, Vol. 34, 145-228.

Ferri, N. (2012): „Vjerovanje i štovanje bogova u predhrišćanskoj Dardaniji“. y: Godišnjak, CBI ANUBIH, 41, 135-158.

Ферјанчић, С. (2002): Насељавање легијских ветерана. Београд: Балканолошки институт САНУ.

Ferjančić, S (2010): „Religija rimske vojske u Gornjoj Meziji: epigrafska svedočanstva“. u: (ur. K. Maricki Gadjanski), Antička kultura, evropsko i srpsko nasleđe, Zbornik radova, Društvo za antičke studije Srbije, Beograd, 465-479.

Hörig, M. / Schwertheimer, E. (1987): Corpus culti lovis Dolicheni. Leiden - New York - Kobenhaven - Köln: Brill.

Čerškov, E. (1969): Rimljani na Kosovu i Metohiji. Beograd: Arheološko društvo Jugoslavije. 


\section{Gligor Samardžić}

\section{JUPITER AND HIS EPITHETS (THE NATURE OF INSCRIPTIONS) FROM THE SOUTH OF THE PROVINCE OF UPPER MOESIA}

(A few examples from Kosovo and Metohija)

The paper presented Jupiter's epithets from the south of the province of Upper Moesia (Kosovo and Metohija). Epigraph staues which testify about the religiousness of the Roman citizens were found in Kosovo and Metohija as well as in areas which were parts of the Roman Empire. The Romans (soldiers, colonists) brought with themselves the respect for the deities of the Roman pantheon among which the most respected one was the supreme Roman god Jupiter Capitolinus. He appears with various epithets attached to his name.

We can observe that Jupiter appears on the statues in Kosovo and Metohija alone or in the Capitoline Triad (with Juno and Minerva) and in the company with other deities. The most common form of dedicated inscription is the abbriviation IOM. However, we observe that significant numbers of epigraph statues from Kosovo and Metohija (the south of Upper Moesia) had, besides Capitoline, following epithets as well: Capitolinus, Cohortalis, Melcid, Melano, Depulsor, Dolicheno. These statues originate mostly from excavated former temples, sanctuaries or private cult areas, or sometimes were the results of accidental findings in the areas not associated with the cult ritual.

The aforementioned epithets show that the emergence of multiple Jupiter cults found in the south of Upper Moesia were marked by syncretism of various cultural elements. The south of Upper Moesia in the ancient times was inhabited not only by the locals but also by the people who moved from other parts of the Roman Empire bringing their material and spiritual culture with them. Therefore, Jupiter Capitolinus, who was the pillar of the state official religion, was present with his cults that were created due to the syncretism of the Roman and oriental religious elements, mostly those from hellenic areas. These cults were spread on the territory of Upper Moesia by the inhabitants of oriental descent (dealing with mine ore production) and the Roman soldiers who were stationed in the eastern provinces of the Empire. 